Agricultural Journal 5 (5): 303-308, 2010

ISSN: $1816-9155$

(C) Medwell Journals, 2010

\title{
Biochemical Characteristics of the African Nutmeg, Monodora myristica
}

\author{
${ }^{1}$ Ekeanyanwu C. Raphael, ${ }^{2} \mathrm{Ogu}$ I. Gideon and ${ }^{2}$ Nwachukwu U. Perpetua \\ ${ }^{1}$ Department of Chemical Sciences, ${ }^{2}$ Department of Biological Sciences, \\ Novena University, Ogume, P.M.B. 02 Kwale, Delta State, Nigeria
}

\begin{abstract}
Proximate, mineral, phytochemical and antinutrients composition of African nutmeg (Monodora myristica) flour were determined using standard analytical techniques. The physicochemical characteristics of the oil were also investigated. The mean values of various parameters for proximate composition were: moisture $(13.15 \pm 2.73 \%)$, total ash $(3.90 \pm 1.05 \%)$, crude fat $(27.77 \pm 2.57 \%)$, crude protein $(10.13 \pm 1.95 \%)$, crude fibre $(23.38 \pm 4.45 \%)$ and carbohydrate (by difference) $(21.2 \%)$. The calculated fatty acids were $23.28 \%$ and energy was

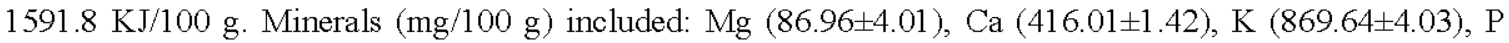
(112.03 \pm 4.63$), \mathrm{Mn}(1.05 \pm 0.35), \mathrm{Fe}(21.71 \pm 0.52), \mathrm{Na}(17.66 \pm 0.32), \mathrm{Cu}(0.19 \pm 0.02), \mathrm{Al}(4.98 \pm 0.68)$ and $\mathrm{Zn}(1.52 \pm 0.11)$ while $\mathrm{Pb}$ was not detected. The relationship between $\mathrm{Na}$ and $\mathrm{K}$ as well as $\mathrm{Ca}$ and $\mathrm{P}$ were desirable with respective ratios of $\mathrm{Na} / \mathrm{K}(0.02)$ and $\mathrm{Ca} / \mathrm{P}(3.71)$. The results of physicochemical properties of African nutmeg seed oil with the mean value of the following parameters-colour (yellow), refractive index (1.477), specific gravity $\left(1.464 \mathrm{~g} \mathrm{~cm}^{-3}\right)$, acid value $\left(66.50 \pm 2.23 \mathrm{mg} \mathrm{KOH} \mathrm{g}{ }^{-1}\right)$, saponification value $\left(414.53 \pm 10.29 \mathrm{mg} \mathrm{KOH} \mathrm{g}^{-1}\right)$, iodine value $\left(101.61 \pm 2.30 \mathrm{mg}\right.$ Iodine $\left.\mathrm{g}^{-1}\right)$, peroxide value $(4.13 \pm 0.40)$ and free fatty acids $\left(33.26 \pm 1.12 \mathrm{mg} \mathrm{g}^{-1}\right)$ indicated that African nutmeg oil is a drying oil may not be suitable for cooking of foods and for soap making. The results of phytochemical screening which revealed the presence of glycosides, cyanogenic glycosides, flavonoids, saponins, tannins, steroids, oxalates and phytates and the antinutrients composition which included tannins $(0.64 \pm 0.08)$, oxalates $(1.05 \pm 0.02)$, cyanogenic glycosides $(0.32 \pm 0.08)$, saponins $(1.58 \pm 0.60)$ and phytates (4.08 \pm 0.10$)$ suggest that the African nutmeg is relatively safe for consumption.
\end{abstract}

Key words: African nutmeg, Monodora myristica, antinutrient composition, oil, physicochemical, Nigeria

\section{INTRODUCTION}

Plants are primary sources of medicines, fibre, food, shelter and other items of every day use by humans. The roots, stems, leaves, flowers, fruit and seeds provide food for animals and human beings (Hemingway, 2004). Plants serve as indispensable constituents of human diet supplying the body with minerals salts, vitamins and certain hormone precursors in addition to protein and energy (Oyenuga and Fetuga, 1975). Seeds have nutritive and calorific values which make them necessary in diets (Odoemelam, 2005). Among these plant seeds are the seeds of Monodora myristica popularly known as African nutmeg.

Morphologically, African nutmeg is a perennial edible plant of the Annanacea family is a berry that grows wild in the evergreen forests of West Africa (Burubai et al., 2009). The seeds are economically and medicinally important (Okafor, 1987; Okigbo, 1977). The kernel obtained from the seeds is a popular condiment used as a spicing agent in both African and continental cuisines in Nigeria. The seeds are embedded in a white sweet-smelling pulp and are most economically important part of the tree. They are aromatic and are used after grinding to a powder as a condiment in food providing flavour resembling that of nutmeg (Myristica fragrans). They are also used as an aromatic stimulating addition to medicine and snuff.

Ground to a powder, they may be taken as a stimulant or stomachic or to relieve constipation. The powder may be sprinkled on sores especially those caused by the guinea worm (Burkill, 1985). There is limited information on the nutritive composition, antinutritive composition and physicochemical properties of the African nutmeg seeds.

There is therefore, the need to augment the available information on African nutmeg research (Burubai et al., 2009). The objective of this study is to investigate the proximate, minerals, phytochemical and antinutrient composition as well as the physicochemical properties of African nutmeg seed flour produced in Delta state, Nigeria.

Corresponding Author: Ekeanyanwu C. Raphael, Department of Chemical Sciences, Novena University, Ogume, P.M.B. 02 Kwale, Delta State, Nigeria 


\section{MATERIALS AND METHODS}

Samples collection and preparation: The African nutmeg seeds sample were collected from a local farm in Obiaruku, Delta state, Nigeria. The seeds were thoroughly screened to remove the bad ones and stones. These were then held at room temperature. The African Nutmeg flour was prepared by grinding the seeds in a laboratory electric mill. The powdered sample was stored in an air tight container and kept in refrigerator at $4^{\circ} \mathrm{C}$ until needed for analyses.

Proximate analyses: The proximate analyses of the samples for moisture, total ash and crude fibre were carried out in triplicate using the methods described by AOAC (1990). The nitrogen was determined by the micro kjedahl method described by Pearson (1976) and the nitrogen content was converted to protein by multiplying by a factor of 6.25 . Carbohydrates were determined by difference method. All the proximate values were reported in percentages.

Mineral analysis: The mineral content was investigated according to AOAC (1990) methods. One gram of dried and ground African nutmeg seeds sample was put in a Pyrex crucible and $10 \mathrm{~mL}$ of pure $\mathrm{HNO}_{3}$ was added. This was incinerated in GallenKamp microwave oven at $250^{\circ} \mathrm{C}$ for $18 \mathrm{~h}$ and was then diluted to the volume of $25 \mathrm{~mL}$ with water. Samples were filtered through a filter paper. The mineral content was then determined using Atomic Absorption Spectrophotometer (Perkin-Elmer Model 403, Norwalk CT, USA). Phosphorus was determined by titration method. All determinations were done in triplicate.

Extraction of oil: The oil sample was extracted from the seeds flour by soxhlet extractor using n-Hexane of Analar grade $\left(\mathrm{BDH}\right.$, London), boiling range $60-80^{\circ} \mathrm{C}$ for $8 \mathrm{~h}$ (James, 1996). After the extraction has been certified completed by the extracting solution being clear, the solvent was distilled off in the distillation set. The oil was then poured into a beaker and left for 5 days for the remaining solvent to evaporate.

Physicochemical analysis of the oil: The physicochemical analysis of the oil for the colour, refractive index, specific gravity, acid value, saponification value, iodine value, peroxide value, free fatty acids and ester value were determined by the methods described by Pearson (1976).

Phytochemical screening: The phytochemical screening of the samples for the presence or absence of phytochemicals such as alkaloids, cyanogenic glycosides, glycosides, flavonoids, resins, saponins, oxalates, phytates and tannins was carried out as described by Harbone (1973) and Sofowora (1980).

Antinutrient analysis: Quantitative determination of oxalates, phytates, tannins, cyanogenic glycosides and saponins were carried out in triplicates, using the method of AOAC (1990).

Statistical analysis: Data obtained was presented in mean \pm standard deviation and analysed by simple percentages. Data collected were statistically analysed for differences by use of students' t-test and simple percentages.

\section{RESULTS AND DISCUSSION}

Proximate composition: Table 1 showed results of the proximate composition of African nutmeg seed flour. The moisture mean value at $13.15 \pm 2.73 \%$ dry weight is comparable with the mean value of moisture of legumes ranging between 7.0 and $11.0 \%$ reported by Aykroyd and Doughty (1964).

However, this value is high compared with those reported by Ige et al. (1984) and Fagbemi and Oshodi (1991) for fluted pumpkins seeds at 5.0 and 5.5\%, respectively and by Aremu et al. (2005) for cashew nut at $5.7 \%$. Ash content mean value of African nutmeg seed in this present study was $3.96 \pm 1.05 \%$. It has been recommended by Pomeranz and Clifton (1981) that ash contents of nuts, seeds and tubers should fall within the range of $1.5-2.5 \%$ in order to be suitable for animal feeds. The ash content of African nutmeg seed does not fall within this range, hence it cannot be recommended for animal feeds.

The crude fat with a mean value of $27.77 \pm 2.59$ is low compared to the values for varieties of melon seeds ranging between 47.9-51.1\% reported by Ige et al. (1984) for pumpkin seed (49.2 and 47.01\%) by Asiegbu (1987) and Fagbemi and Oshodi (1991) and for cashew nut (36.7\%) by Aremu et al. (2006) but is high compared to soya bean seed which has only $23.5 \%$ fat (Paul and Southgate, 1980). Fat is important in diets because it

Table 1: Proximate composition (\%) of African nutmeg seed flour

\begin{tabular}{ll}
\hline Composition & Percentage \\
\hline Moisture & $13.15 \pm 2.73$ \\
Total Ash & $3.90 \pm 1.05$ \\
Crude fat & $29.1 \pm 0.93$ \\
Crude protein & $10.13 \pm 1.95$ \\
Crude fiber & $25.9 \pm 0.87$ \\
Carbohy drate (by difference) & 21.2 \\
${ }^{a}$ Fatty acids & 23.28 \\
${ }^{b}$ Energy KJ $/ 100 \mathrm{~g}$ & 1591.8 \\
\hline
\end{tabular}


Agric. J., 5(5): 303-308, 2010

promotes fat soluble vitamin absorption (Bogert et al., 1994). It is a high energy nutrient and does not add to the bulk of the diet.

The crude protein of $10.13 \pm 1.95 \%$ is somehow low compared to protein rich foods such as soybeans, cowpeas, pigeon peas, melon, pumpkin and gourd seeds that range between 23.1 and $33.0 \%$ (Olaofe et al., 1994); chick beans (19.4\%) and lima bean (19.8\%) (FAO, 1982 ) and Jack bean, 30.8\% (Anonymous, 1972). The recommended daily allowance for protein for children ranges from 23.0-36.0 g and for adults, 44-56 g (NRC, 1989). Apart from the nutritional significance of protein as a source of amino acids, they also play a part in the organoleptic properties of food (Aremu et al., 2006).

The crude fibre of African nutmeg was very high compared to legumes mean values that range between 5 and 6\% (Aremu et al., 2006; Anonymous, 1972). Maintenance of internal distension for a normal peristaltic movement of the intestinal tract is the physiological role which crude fibre plays. Okon (1983) reported that a diet low in fibre is undesirable as it could cause constipation and that such diet has been associated with diseases of the colon like pile, appendicitis and cancer. The net value for carbohydrate (by difference) at $21.2 \%$ is comparable to the acceptable range mean values of legumes $(20-60 \%)$ of dry weight (Aykroyd and Doughty, 1964).

This result also gave an indication that the African nutmeg flour could be a rich source of energy and supports its inclusion in diets. The calculated metabolizable energy value $(1591.8 \mathrm{KJ} / 100 \mathrm{~g})$ showed that African nutmeg was a good source of energy. The energy from cereals ranged from 1.3-1.6 MJ/100 g reported by Paul and Southgate (1980) indicating that African nutmeg flour has energy concentration favourably compared to cereals.

Mineral composition: The mineral contents ( $\mathrm{mg} / 100 \mathrm{~g}$ ) of African nutmeg flour were shown in Table 2. The least abundant minerals were $\mathrm{Mn}, \mathrm{Cu}, \mathrm{Al}$ and $\mathrm{Zn}$ while $\mathrm{K}$ was found to be the most abundant $(869.64 \pm 4.03 \mathrm{mg} / 100 \mathrm{~g})$. This is in close agreement with the observation of Olaofe and Sanni (1988) and Aremu et al. (2006) that potassium was the most predominant mineral in Nigerian agricultural products.

Calcium was found to be next highest mineral component. Calcium in conjunction with phosphorus, magnesium, manganese, vitamin $\mathrm{A}, \mathrm{C}$ and $\mathrm{D}$, chlorine and protein are involved in bone formation (Fleck, 1976). Calcium is also important in blood clothing, muscle contraction and in certain enzymes in metabolic processes. Magnesium mean value $(86.96 \pm 4.01)$ is high compared to values $(36.4 \pm 0.2)$ reported by Aremu et al. (2005) for cashew nut flour. It has been
Table 2: Mineral contents $(\mathrm{mg} / 100 \mathrm{~g})$ of African nutmeg seed flour

\begin{tabular}{ll} 
Minerals & $\mathrm{Mg} / 100 \mathrm{~g}$ \\
\hline $\mathrm{Mg}$ & $86.96 \pm 4.01$ \\
$\mathrm{Ca}$ & $416.01 \pm 1.42$ \\
$\mathrm{~K}$ & $869.64 \pm 4.03$ \\
$\mathrm{P}$ & $112.03 \pm 4.63$ \\
$\mathrm{Mn}$ & $1.05 \pm 0.35$ \\
$\mathrm{Fe}$ & $21.71 \pm 0.52$ \\
$\mathrm{Na}$ & $17.66 \pm 0.32$ \\
$\mathrm{Cu}$ & $0.19 \pm 0.02$ \\
$\mathrm{Al}$ & $4.98 \pm 0.68$ \\
$\mathrm{~Pb}$ & $\mathrm{ND}$ \\
$\mathrm{Zn}$ & $1.52 \pm 0.11$ \\
$\mathrm{Na} / \mathrm{K}$ & 0.02 \\
$\mathrm{Ca} / \mathrm{P}$ & 3.71 \\
\hline
\end{tabular}

Values are mean \pm standard deviation of triplicate determinations. $\mathrm{ND}=\mathrm{Not}$ Detected

Table 3: Phy sicochemical properties of African nutmeg seed flour oil

Parameters Values

Colour $\quad$ Yellow

Refractive index

1.477

Specific gravity $\left(\mathrm{g} \mathrm{cm}^{-3}\right)$

Acid value $\left(\mathrm{mgKOH} \mathrm{g}^{-1}\right)^{\mathrm{a}}$

1.477
1.464

$66.50 \pm 2.23$

$\begin{array}{ll}\text { Saponification value }(\mathrm{mgKOH} \mathrm{g} & -1 \\ { }^{\mathrm{a}} & 414.53 \pm 10.29\end{array}$

Iodine value (mgIodine $\left.\mathrm{g}^{-1}\right)^{\mathrm{a}} \quad 101.61 \pm 2.30$

Peroxide value ${ }^{a}$

4. $13 \pm 0.40$

Free fatty acids $\left(\mathrm{mg} \mathrm{g}^{-1}\right)^{\mathrm{a}}$

$33.26 \pm 1.12$

Ester value ( $\left.\mathrm{mg} \mathrm{KOH} \mathrm{g}^{-1}\right)^{\mathrm{a}}$

${ }^{a}$ Values are mean \pm standard deviation of triplicate determinations

reported that magnesium is an activator of many enzymes systems and maintains the electrical potential in nerves (Ferrao et al., 1987). The mean value of phosphorus $(112.03 \pm 4.63)$ is lower than that of calcium. Phosphorus is always found with calcium in the body both contributing to the blood. Low $\mathrm{Ca} / \mathrm{P}$ ratio of African nutmeg flour is $>1$, indicating that it would serve as good sources of mineral for bone formation.

The ratio of sodium to potassium in the body is of great concern for prevention of high blood pressure. $\mathrm{Na} / \mathrm{K}$ ratio $<1$ is recommended (Nieman et al., 1992). This is an indication that the inclusion of African nutmeg in the diet would probably reduce high blood pressure diseases.

\section{Physicochemical properties of African nutmeg seed flour} oil: The physicochemical properties of African nutmeg seed oil were shown in Table 3 . The yellow coloured oil had specific gravity of 1.464 indicating that it is denser than water with refractive index of 1.477 . The refractive index is comparable with the values reported for most drying oils whose refractive indices were between 1.475 and 1.485 (Duel, 1951). The saponification value of the oil was $414.53 \pm 10.29 \mathrm{mg} \mathrm{KOH} \mathrm{g}^{-1}$ which is higher than that reported for most vegetables such as coconut oil (255 $\mathrm{mg} \mathrm{KOH} \mathrm{g}^{-1}$ ), palm kernel oil ( $247 \mathrm{mg} \mathrm{KOH} \mathrm{g}^{-1}$ ) and butter fat $\left(225 \mathrm{mg} \mathrm{KOH} \mathrm{g}^{-1}\right)$. It has been reported by Pearson (1976) that oils with higher saponification values contains high proportion of lower fatty acids. Therefore, 
the values obtained for African nutmeg oil indicated that the oil contained high proportion of lower fatty acids. Because of this value, it is not economical for soap making, as it will require a large quantity of $\mathrm{KOH}$. The iodine value $\left(101.61 \pm 2.30 \mathrm{mg}\right.$ Iodine $\left.\mathrm{g}^{-1}\right)$ of African nutmeg oil is much higher than the values reported for cashew nut oil, with value of $44.4 \pm 0.1 \mathrm{mg}$ Iodine $\mathrm{g}^{-1}$, Citrullis vulgaris with value $38.1 \pm 3 \mathrm{mg}$ Iodine $\mathrm{g}^{-1}$ (Achinewhu, 1990) and Hausa melon seed, $38.50 \pm 0.67 \mathrm{mg}$ Iodine $\mathrm{g}^{-1}$ (Oladimeji et al., 2001). These are all nondrying oils.

In view of the fact that drying oils have an iodine value above 100 (Duel, 1951), African nutmeg oil could only be categorised as a drying oil. The free fatty acid value $\left(33.26 \pm 1.12 \mathrm{mg} \mathrm{g}^{-1}\right)$ of African nutmeg oil is higher than that reported for cashew nut oil, $28.4 \pm 0.1 \mathrm{mg} \mathrm{g}^{-1}$ by Aremu et al. (2006). The lower the free fatty acid value, the better the quality of the oil. The oil had a very high acid value of $66.50 \pm 2.23 \mathrm{mg} \mathrm{KOH}$ when compared with Plukenetia conophora $\left(11.5 \mathrm{mg} \mathrm{KOH} \mathrm{g}{ }^{-1}\right)$ as reported by Akintayo and Bayer (2002) and Benniseed (47.6\%) reported by Oshodi (1992).

Phytochemical profile of African nutmeg seed flour: The phytochemical profile of African nutmeg seed flour is shown in Table 4. The phytochemical screening revealed that Monodora myristica is rich in glycosides, flavonoids, saponins and steroids but with very little cyanogenic glycosides, tannins, oxalates and phytates. Flavonoids, saponins and tannins are known to have antimicrobial activity, as well as other physiological activities (Sofowora, 1980; Evans, 2005). In fact, flavonoids have a wide range of biochemical and pharmacological activities in mammalian and other biological systems. They possess anti-inflammatory, anti-oxidant, anti-allergic, hepatoprotective, anti-thrombic, antiviral and anticarcinogenic activities (Middleton et al., 2000).

The concentration of some of the antinutrients was shown in Table 5. The results revealed low levels of oxalates $(1.05 \pm 0.02 \mathrm{mg} / 100 \mathrm{~g})$ when compared with other plant seeds such as Buccholzia coricea which had a value of $1.06 \mathrm{mg} / 100 \mathrm{~g}$, Solanum nigrum which had a value of $58.81 \mathrm{mg} / 100 \mathrm{~g}$ and Gnetum africanum with value of $209.00 \mathrm{mg} / 100 \mathrm{~g}$ (Amaechi, 2009; Akubugwo et al., 2007; Ekop, 2007).

Tannins was quite low, while saponin content was a bit higher $(1.58 \pm 0.60 \mathrm{mg} / 100 \mathrm{~g})$ than the value of saponin content of $S$. nigrum seeds with value of $0.66 \pm 0.01$ $\mathrm{mg} / 100 \mathrm{~g}$ discovered by Akubugwo et al. (2007). Saponin as an antinutrient has been reported to possess both
Table 4: Phy tochemical profile of African nutmeg seed flour

\begin{tabular}{ll}
\hline Phytochemicals & Results \\
\hline Alkaloids & - \\
Glycosides & ++ \\
Cyanogenic glycosides & + \\
Flavonoids & ++ \\
Saponins & ++ \\
Tannins & + \\
Steroids & ++ \\
Oxalates & + \\
Phytates & + \\
\hline
\end{tabular}

$+=$ slightly present, $++=$ moderately present, $++=$ highly present

Table 5: Some anti-nutritional contents of Afric an nutmeg flour

\begin{tabular}{lc}
\hline Antinutrients & Composition $(\mathrm{mg} / 100 \mathrm{~g})$ \\
\hline Oxalates & $1.05 \pm 0.02$ \\
Phytates & $4.08 \pm 0.10$ \\
Tannins & $0.64 \pm 0.08$ \\
Cyanogenic glycosides & $0.32 \pm 0.08$ \\
Saponins & $1.58 \pm 0.60$ \\
\hline
\end{tabular}

Values are mean \pm standard deviation of triplicate determination

beneficial and deleterious properties and exhibit structure dependent biological activity (Savage, 1993). A phytate level of $4.08 \pm 0.10 \mathrm{mg} / 100 \mathrm{~g}$ was observed. The knowledge of phytate level in foods is necessary because high concentration could cause adverse effects on the digestibility (Akintayo and Bayer, 2002). Phytate forms stable complexes with $\mathrm{Cu}^{2+}, \mathrm{Zn}^{2+}, \mathrm{Co}^{2+}, \mathrm{Mn}^{2+}, \mathrm{Fe}^{2+}$ and $\mathrm{Ca}^{2+}$.

\section{CONCLUSION}

The present study indicated that African nutmeg is rich in important food nutrients compared to some oil seeds and nuts. The physicochemical properties of the oil indicated that it is a drying oil, so may not be very suitable for human consumption and due to its high saponification value may not be good for soap making. The phytochemical screening of African nutmeg seeds showed that it contains some important phytochemicals. The antinutrients analysis indicated that African nutmeg has a low concentration of some antinutrients.

\section{REFERENCES}

AOAC, 1990. Official Methods of Analysis. 15th Edn., Association of Official Analytical Chemists, Washington, DC., USA., pp: 200-210.

Achinewhu, S.C., 1990. Composition and food potential of melon seed (C. vulgaris). Nig. Food J., 8: 130-133.

Akintayo, E.T. and E. Bayer, 2002. Characterization and some possible uses of Plukenetia conophora and Adenopus breviflorus seeds and seed oils. Bioresour. Technol., 85: 95-97. 
Akubugwo, I.E., A.N. Obasi and S.C. Ginika, 2007. Nutritional potential of leaves and seeds of black nightshade Solanum nigrum L. Var virginicum from Afikpo-Nigeria. Pak. J. Nutr., 6: 323-326.

Amaechi, N.C., 2009. Nutritive and antinutritive evaluation of wonderful Kola (Buccholzia coricea) seeds. Pak. J. Nutr., 8: 1120-1122.

Anonymous, 1972. Tropical Legumes: Resources of the Future. National Academy of Science, Washington DC.

Aremu, M.O., A. NOlanisakin, J.W. Otene and B.O. Atolaye, 2005. Mineral content of some agricultural products grown in the middle belt region of Nigeria. Oriental J. Chem., 21: 419-426.

Aremu, M.O., A. Olonisakin, D.A. Bako and P.C. Madu, 2006. Compositional studies and physicochemical characteristics of cashew nut (Anarcadium occidentale) flour. Pak. J. Nutr., 5: 328-333.

Asiegbu, I.E., 1987. Some biochemical evaluation of fluted pumpkin seed. J. Sci. Food Agric., 40: 151-155.

Aykroyd, W.K. and J. Doughty, 1964. Legumes in Human Nutrition. 1st Edn., Food and Agriculture Organization of the United Nations, Rome, Italy, ISBN-10: 9251004404, pp: 125.

Bogert, J.L., G.M. Briggs and D.H. Galloway, 1994. Nutrition and physical fitness. Int. J. Food Sci. Nutr., 45: $223-230$.

Burkill, H.M., 1985. The Useful Plants of West Tropical Africa. Vol. 1, Royal Botanic Gardens, Kew, ISBN: $094764301 \mathrm{X}$, pp: 960.

Burubai, W., E. Amula, P. Daworiye, T. Suowari and P. Nimame, 2009. Proximate composition and some technological properties of African nutmeg (Monodora myristica) seeds. Electron. J. Environ. Agric. Food Chem., 8: 396-402.

Duel, H.J.Jr., 1951. The Lipids: Their Chemistry and Biochemistry. Vol. 1. Inter Science Publishers, New York, pp: 53-57.

Ekop, A.S., 2007. Determination of chemical composition of Gnetum africanum (AFANG) seeds. Pak. J. Nutr., 6: $40-43$.

Evans, W.C., 2005. Trease and Evans Pharmacognosy. 15th Edn., Division of Reed Elsevier India Pvt. Ltd., New Delhi, India, ISBN-13: 978-81-312-0087-2.

$\mathrm{FAO}$, 1982. Composition Table for Use in Africa. Development of Health Education and Welfare, Health Science and FAO Nutrition Division, Rome, Italy, pp: 32.

Fagbemi, T.N. and A.A. Oshodi, 1991. Chemical composition and functional properties of full-fat fluted pumpkin seed flour (Telfairia occidentalis). Nig. Food J., 9: 26-32.
Ferrao, J.E.M., A.M.B.C. Ferro and A.M.G. Antures, 1987. Bambara groundnut (Vigna subteranean): Aspect of its nutritive value Gracia Deorta Seriede. Estudos Agronomics, 14: 35-39.

Fleck, H., 1976. Introduction to Nutrition. 3rd Edn., Macmillian Publishing Co. Inc., New York, pp: 552.

Harbone, J.B., 1973. Phytochemical Methods: A Guide to Modern Technique of Plant Analysis. 2nd Edn., Chapman and Hall, London.

Hemingway, C.A., 2004. Plants and People. Edible Plant J., pp: 1.

Ige, M.N., A.O. Ogunsua and O.L. Oke, 1984. Functional properties of the protein of some Nigerian oil seeds: Casaphor seeds and three varieties of some Nigeria oil seeds. J. Agric. Food Chem., 32: 822-825.

James, C.S., 1996. Analytical Chemistry of Foods. Chapman and Hall, New York.

Middleton, E., C. Kandaswami and T.C. Theoharides, 2000. The Effect of plant flavonoids on mammalian cells: Implications for inflammation, heart disease and cancer. Pharmcol. Rev., 52: 678-751.

NRC, 1989. Recommended Dietary Allowances. 10th Edn., National Academy Press, Washington, DC. USA., pp: 284.

Nieman, D.C., D.E. Butterworth and C.N. Nieman, 1992. Nutrition. WMC. Brown Publisher, Dubugue, pp: 50.

Odoemelam, S.A., 2005. Proximate composition and selected physicochemical properties of the seeds of African oil bean (Pentaclethra marcrophylla). Pak. J. Nutr., 4: 382-383.

Okafor, J.C., 1987. Development of forest tree crops for food supplies in Nigeria. Forest Ecol. Manage., 1: 235-247.

Okigbo, B.N., 1977. Neglected plants of horticultural importance in traditional farming systems of tropical Africa. Acta Hortic., 53: 131-150.

Okon, B.D., 1983. Studies on the chemical composition and nutritive value of the fruits of African star apple. M.Sc. Thesis, University of Calabar, Nigeria.

Oladimeji, M.O., A.O. Adebayo and A.H. Adegbesan, 2001. Physicochemical properties of hausa melon seed flour. Ultra Sci., 13: 374-377.

Olaofe, O. and C.O. Sanni, 1988. Minerals contents of agriculture products. Food Chem., 30: 73-77.

Olaofe, O., F.O. Adeyemi and G.O. Adediran, 1994. Amino acid and mineral composition and functional properties of some oil seeds. J. Agric. Food Chem., 42: 878-884.

Oshodi, A.A., 1992. Proximate composition nutritionally valuable minerals and functional properties of Adenopus brevriflorus bent seed flour. Food Chem., 45: 79-83. 
Oyenuga, V.A. and B.L. Fetuga, 1975. First nutritiona 1 seminar on fruits and vegetables. Proceeding and Recom Papers, NIHORT, Ibadan.

Paul, A.A. and B.A.T. Southgate, 1980. Mucance and Widdowson's Consumption of Food. 4th Edn., Her Majesty's Stationary Office, London, UK., pp: $227-228$.

Pearson, D., 1976. The Chemical Analysis of Foods. 7th Edn., Churchill Livingstone, London, ISBN: 0443014116 , pp: 7-11.
Pomeranz, V. and D. Clifton, 1981. Properties of defatted soybean, peanut, field pea and pecan flours. J. Food Sci., 42: 1440-1450.

Savage, G.P., 1993. Saponins. In: Encyclopaedia of Food Science Food Technology and Nutrition, Macrae, R., R.K. Robinson and M.J. Sadler (Eds.). Academic Press, London.

Sofowora, A., 1980. Guidelines for research promotion and development in traditional medicine. Nig. J. Pharmacy, 11: 117-118. 